\title{
Investigation of Stomata Densities in Pea (Pisum sativum L.) Lines/Cultivars
}

\author{
Hatice Bozoglu and Reyhan Karayel \\ Ondokuz Mayıs University, Faculty of Agriculture, Agronomy Department \\ Kurupelit-Samsun, 55139-Turkey
}

\begin{abstract}
This study were conducted to determine, if stomata density can be used as a criterion in cultivar differentiation or not. In this study, density of stomatas in stipula and abaxial and adaxial surface of leaflets was determined in the flowering and pod set period of 23 pea cultivars and lines that were sowed as wintertime for 2 years. The effect of years on the stomata density in other parts sections except for the stomata numbers in stipula and leaflet adaxial surface were determined on the level of statistical significance. In pod setting period, stomata numbers were higher compared to the flowering period. Stomata number in leaf section of the 5 cultivars used in the trial is in general higher than those of the lines. The determination of year $x$ genotype interaction in the study shows that there is not enough evidence for using this characteristic for cultivar differentiation.
\end{abstract}

Key words: Pea, stomata density

\section{INTRODUCTION}

Primitive forms and local species as a genetic base are important genetic sources in solving the possible future problems in culture plants and transferring new characteristics to culture plants ${ }^{[1]}$ Turkey is one of the few geographies that is in central position of the origin and diversity of many plant species. Pea is also one of these genetic sources ${ }^{[2]}$. Conservation and development of local gene sources is one of our country's primary study fields as it is in the entire world.

Development of cytology and genetic science which are concerned with cell structure and functions have given genetic breeder new visions and the possibility to obtain results in shorter ways. Stomatas, the cell structure where plants' gas exchanges to take place and water vapour to be lost, can also be evaluated in this context.

Stomatas are organelles that effect adaptation skills of plants ${ }^{[3]}$ by directing transpiration and photosynthesis and are used in taxonomic differentiation ${ }^{[4]}$ and give clues about plant culture when how they are effected from environmental factors is determined. In a study that researches macro and micro element concentrations and stomata numbers in 4 wintertime wheat genotypes in two different locations, the obtained results indicate that the number of stomata per $\mathrm{mm}^{2}$ and macromicroelement concentrations depended on the genotype, phenotype and locality. A statistically significant correlation was found between the stomata number per $\mathrm{mm}^{2}$ and the macro and micro element concentrations $^{[5]}$. Stomata numbers can change according to species and cultivars ${ }^{[6,7]}$. Other researcher ${ }^{[8]}$ have informed that stomata are stably inherited and can be used to distinguish cultivars and lines of apples. A comparative study was conducted on the foliar epidermis and venation pattern of Aquilaria khasiana and 3 phenotypic variants of A. malaccensis in North-East India. Some quantitative values such as stomata $/ \mathrm{mm}^{2}$, stomatal size, stomatal index, size of aeroles are very significant in differentiating the taxa at species and interspecies level ${ }^{[4]}$.

In some resources, it has been informed that stomata density changes with characteristics such as dependence on drought, net photosynthesis production $^{[9]}$, vegetative development phases ${ }^{[7]}$ and altitude $^{[10]}$. A study that researches round seedless grape cultivar' leaf characteristics and stomata distribution, determined that stomata density changed in relation to the years and cultivars and there was no correlation between stomata numbers and leaf characteristics ${ }^{[11]}$. Besides that it was established that stomata density was an important factor in resistance against diseases. It is proposed that stomata density and conductance of lower leaves on tabacco plant be used as a selection marker for disease-resistance breeding ${ }^{[12]}$. Another results of experiment showed that the resistance of downy mildew in cucumber was negatively correlated to stomatal density ${ }^{[13]}$.

Pea which has a widespread variety of use in different regions of world, has the largest sowing area in the world after beans and chickpeas and has the largest production value after the bean. Furthermore, pea is an important grain legume that has the highest unit area yield in our country and the world and its farming is concentrated more in developed countries ${ }^{[14]}$. Given that it has started genetic studies, pea has a special place in the world of plants. Our country being one of the genetic sources despite that we do not have enough genetically improved cultivars and our region's suitability for the adaptation requests have forced us to 
study peas. In breeding studies aimed at cultivar development, data about cellular structures are useful in shortening the process. There has been no study about stomata in peas in our country. In this research, by determining a different development stage in pea and stomatal density in leaf section, whether the stomata number is characteristic that can be used in cultivar differentiation has been investigated.

\section{MATERIAL AND METHODS}

Characteristics of Research Location : The trial has been carried out for 2 years in Agriculture Faculty application field which is in OMU campus in SamsunTurkey and has approximately $176 \mathrm{~m}$ elevation from the sea. According to soil analysis results, the trial field has clay nature, neutral $\mathrm{pH}$ and unsalty characteristics. The soil was rich in organic material and poor in calcium. Phosphorus level was high.

In Samsun province located in Middle Blacksea Region coastal section, north of Turkey, winters are temperate and rainy. Generally, important part of the rain falls down in winter months when the plant development is very slow and the rain amount is less in summer months when the plants develop fast. Climate values of Samsun province for long year average (19742003) and years of 2004-2005 when the study was conducted has been given in Fig. 1 and 2 by considering the cultivation period of pea sowed as wintertime.

Material : In this study, lines belonging to $P$. sativum species which has been obtained from National Plant Gene Bank and collected from different locations of our country and 5 pieces of commercial pea cultivars which are added as controls (Klein Rheinlanderin, Sprinter, Lancet, Bolero, Erbs Norli) are composed of 23 genotypes. Peas that come from the Gene Bank were first selected and grouped among themselves by considering the seed colors and seeds of lines that sown in this study were selected by considering their plant characteristics in 3 year field studies.

Method : The research has been conducted for 2 years, in 2003-2004 and 2004-2005 cultivation periods. Pea line/cultivars have been sowed in October as 2 rows in every plot and with $50 \times 10 \mathrm{~cm}$ sowing density for both years. In February calcium ammonium nitrate fertilizer was given to the land of 1000 square meters by $4 \mathrm{~kg} \mathrm{~N}$ calculation. Weeds were prevented by hue in necessary situations.

The leaf samples for stomata observations have been collected for both years in two periods which are the beginning of flowering and the beginning of pod setting periods. Samples have been taken at 9 o'clock in the morning from the leaves on 4 plants in every line/cultivar, in the 8th node in flowering period and 11 th node of same plant in pod setting period.

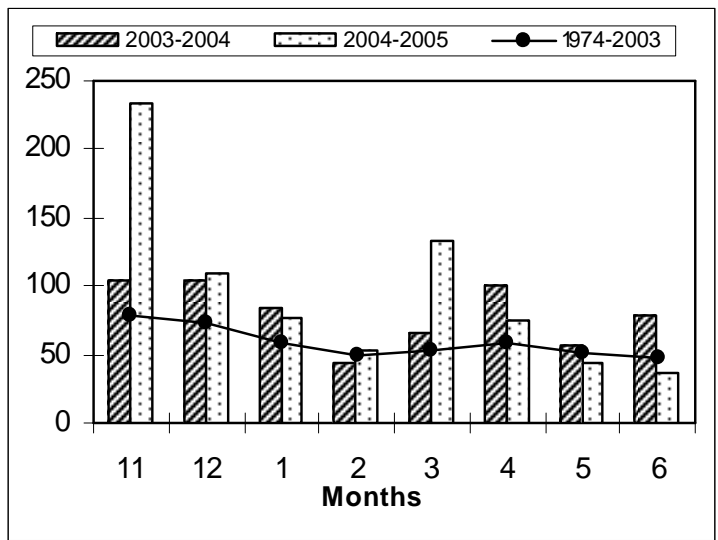

Fig. 1: Monthly total rainfall (mm/ month) of experiment area

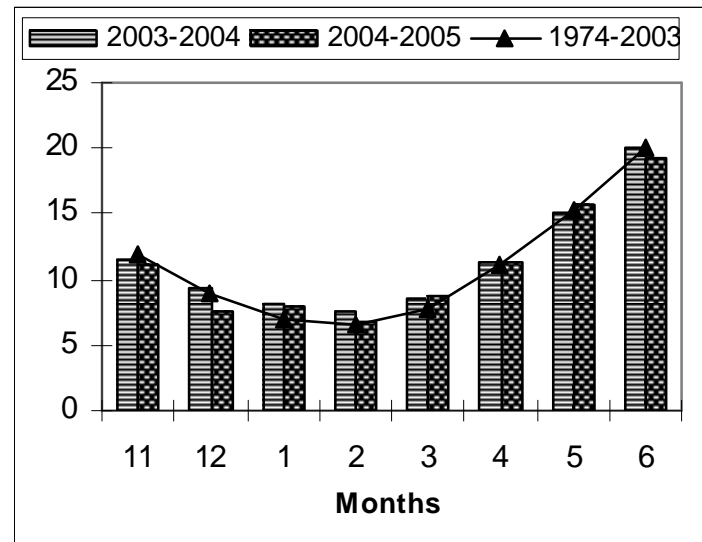

Fig. 2: Monthly average temperature $\left({ }^{\circ} \mathrm{C}\right)$ of experiment area

Leaves are named according to location of stomatas in the leaves and pea leaves have the amphistomic leaf type which has stomatas in both of the surfaces ${ }^{[15]}$. Given this information, by using stipulas and leaflets closest to the stipula, stomata counts have been made in the abaxial surface of one and the adaxial surface of the other. To make the casts of leaflet and abaxial and adaxial of surfaces stipula that are to be counted, nail polish has been applied and dried. After that, these surfaces have been cut in 2-2.5 $\mathrm{cm}^{2}$ dimensions and stomata included membran of leaf have been removed with nail polish by using sticky acetate papers and were transferred to microscope slides. Stomata numbers on every sample surface has been determined in 5 different microscopic view fields by looking through 40x10 magnifying lenses and the figures have been given after being converted to stomata numbers in $1 \mathrm{~mm}^{2}$.

The averages and standard errors of all data belonging to stomata numbers have been determined for every line/cultivars. $t$ test has been applied to comparisons by considering the year, plant 
development period and the locations of analyzed leaf organs.

\section{RESULT AND DISCUSSION}

Stomata numbers in unit leaf area has effect on gas exchange ${ }^{[3]}$. The variation of stomata number in genotype effects gas exchange and eventually the adaptation ability. 23 pea line/cultivars have been used in this research. 18 of these are local lines. This material has been collected from the different locations of the country and was exposed to selection.

By determining stomatas in different leaf sections of 23 pea lines/cultivars separately in flowering and pod setting periods, their average and standard errors have been found and given in Table 1 . These averages are obtained by figures counted in 2 years, in 4 plants in every line/cultivar and in 5 microscopic view fields in every sample. Generally higher stomata number was observed in all leaf sections of registered cultivars compared to the domestic lines (Table 1). When the standard errors of lines were checked, they were small values and this shows that the samples in lines, where stomata counts were made, were as homogeneous as possible.

All cultivars showed dwarf plant characteristic and have small leaves. Lines Bz2, Bz4, Bz7, Bz8, Bz9, Bz12, Bz16 of the used domestic lines have been determined to be tall in plant height grouping and small sized in leaflet size grouping done by considering EU CPOV and UPOV criteria. In this group of lines, in paired comparisons done by considering stomata numbers in abaxial surfaces, both statistical differences (in comparison of $\mathrm{Bz} 2$ and $\mathrm{Bz} 4 \mathrm{t}=2.5^{*}$, in $\mathrm{Bz} 2$ and $\mathrm{Bz} 8$ $\mathrm{t}=2.6^{*}$ ) and similarities (in paired comparison of $\mathrm{Bz} 7$ and $\mathrm{Bz} 8 \mathrm{t}=1.11$, in $\mathrm{Bz} 8$ and $\mathrm{Bz} 9 \mathrm{t}=1.04$ ) were observed. The same situation holds true for registered cultivars as well. When the comparison of stomata number in abaxial leaflet was made between Klein Rheinlanderin which has the same plant cultivar $\left(69.45 / \mathrm{mm}^{2}\right)$ and Erbs Norli $\left(87.9 / \mathrm{mm}^{2}\right)$, statistical difference was observed but when comparison was made between Erbs Norli and Sprinter $\left(82.35 / \mathrm{mm}^{2}\right)$ and between Sprinter and Lancet $\left(73.02 / \mathrm{mm}^{2}\right)$, no statistical difference was observed.

Table 1: Stomata averages and standart errors of leaf sections of various pea genotypes that change in flowering and pod setting phases

\begin{tabular}{|c|c|c|c|c|c|c|c|c|}
\hline \multirow{4}{*}{ Genotype } & \multicolumn{4}{|c|}{ In flowering } & \multicolumn{4}{|c|}{ In pod setting } \\
\hline & \multicolumn{2}{|c|}{ Stipula } & \multicolumn{2}{|c|}{ Leaflet } & \multicolumn{2}{|c|}{ Stipula } & \multicolumn{2}{|c|}{ Leaflet } \\
\hline & $\begin{array}{c}\text { Abaxial } \\
(1) \\
\end{array}$ & $\begin{array}{c}\text { Adaxial } \\
\text { (2) }\end{array}$ & $\begin{array}{c}\text { Abaxial } \\
(3) \\
\end{array}$ & $\begin{array}{c}\text { Adaxial } \\
(4)\end{array}$ & $\begin{array}{c}\text { Abaxial } \\
(5)\end{array}$ & $\begin{array}{c}\text { Adaxial } \\
(6)\end{array}$ & $\begin{array}{c}\text { Abaxial } \\
(7)\end{array}$ & $\begin{array}{c}\text { Adaxial } \\
(8)\end{array}$ \\
\hline & $\bar{X} \pm \mathrm{S}_{\bar{x}}^{-}$ & $\bar{X} \pm \mathrm{S}_{\bar{x}}^{-}$ & $\bar{X} \pm \mathrm{S}_{\bar{x}}^{-}$ & $\bar{X} \pm \mathrm{S}_{\bar{x}}$ & $\bar{X} \pm \mathrm{S}_{\bar{x}}$ & $\bar{X} \pm \mathrm{S}_{\bar{x}}$ & $\bar{X} \pm \mathrm{S}_{\bar{x}}$ & $\bar{X} \pm \mathrm{S}_{\bar{x}}$ \\
\hline $\mathrm{Bz} 1$ & $81.0 \pm 9.2$ & $58.1 \pm 2.7$ & $64.7 \pm 5.2$ & $52.6 \pm 4.8$ & $43.5 \pm 5.3$ & $29.0 \pm 3.2$ & $57.0 \pm 7.7$ & $39.3 \pm 5.6$ \\
\hline Bz 2 & $76.1 \pm 5.0$ & $53.9 \pm 3.3$ & $70.7 \pm 4.0$ & $75.8 \pm 4.3$ & $83.5 \pm 2.8$ & $49.6 \pm 2.2$ & $84.1 \pm 3.2$ & $57.7 \pm 2.3$ \\
\hline Bz 3 & $58.1 \pm 2.3$ & $46.5 \pm 2.4$ & $71.4 \pm 3.8$ & $68.7 \pm 3.6$ & $72.5 \pm 3.1$ & $40.2 \pm 2.2$ & $75.5 \pm 3.4$ & $63.3 \pm 2.6$ \\
\hline $\mathrm{Bz} 4$ & $60.3 \pm 2.8$ & $37.8 \pm 1.7$ & $59.6 \pm 1.9$ & $56.8 \pm 3.2$ & $63.1 \pm 2.7$ & $37.4 \pm 2.0$ & $71.3 \pm 5.7$ & $55.2 \pm 5.1$ \\
\hline Bz 5 & $60.7 \pm 4.3$ & $46.6 \pm 3.1$ & $63.1 \pm 4.3$ & $64.3 \pm 2.6$ & $63.2 \pm 2.6$ & $41.7 \pm 2.0$ & $66.7 \pm 0.3$ & $56.1 \pm 2.5$ \\
\hline Bz 6 & $61.1 \pm 2.0$ & $39.7 \pm 2.0$ & $72.2 \pm 3.5$ & $55.7 \pm 3.6$ & $73.9 \pm 3.5$ & $33.5 \pm 1.2$ & $69.4 \pm 4.0$ & $55.1 \pm 2.5$ \\
\hline Bz 7 & $62.5 \pm 2.9$ & $40.3 \pm 2.7$ & $61.7 \pm 2.7$ & $48.2 \pm 2.5$ & $65.1 \pm 2.4$ & $37.9 \pm 2.4$ & $71.4 \pm 3.8$ & $51.8 \pm 3.3$ \\
\hline Bz 8 & $62.5 \pm 3.9$ & $44.4 \pm 3.7$ & $57.2 \pm 3.4$ & $67.7 \pm 4.7$ & $79.4 \pm 4.3$ & $42.1 \pm 2.1$ & $81.8 \pm 3.3$ & $63.9 \pm 3.3$ \\
\hline Bz 9 & $52.2 \pm 3.1$ & $43.5 \pm 3.3$ & $43.2 \pm 2.3$ & $50.0 \pm 2.3$ & $88.3 \pm 4.6$ & $45.8 \pm 1.9$ & $70.6 \pm 4.2$ & $62.7 \pm 3.0$ \\
\hline $\mathrm{Bz} 10$ & $48.6 \pm 1.8$ & $40.1 \pm 2.1$ & $47.6 \pm 2.5$ & $55.4 \pm 2.3$ & $68.6 \pm 3.4$ & $46.4 \pm 2.3$ & $65.5 \pm 3.4$ & $57.3 \pm 2.1$ \\
\hline Bz 11 & $50.2 \pm 1.9$ & $37.3 \pm 1.7$ & $51.4 \pm 2.3$ & $48.0 \pm 2.2$ & $69.4 \pm 4.8$ & $36.1 \pm 1.9$ & $74.4 \pm 4.9$ & $40.9 \pm 3.4$ \\
\hline Bz 12 & $50.8 \pm 4.3$ & $40.1 \pm 4.5$ & $51.8 \pm 6.9$ & $54.0 \pm 3.9$ & $72.6 \pm 4.1$ & $33.3 \pm 2.2$ & $73.2 \pm 4.7$ & $50.2 \pm 3.2$ \\
\hline Bz 13 & $56.2 \pm 2.7$ & $41.1 \pm 1.7$ & $50.4 \pm 2.6$ & $49.4 \pm 2.3$ & $65.1 \pm 3.2$ & $35.1 \pm 2.2$ & $57.2 \pm 3.0$ & $45.4 \pm 1.9$ \\
\hline Bz 14 & $59.5 \pm 3.9$ & $45.6 \pm 5.2$ & $62.3 \pm 4.0$ & $54.4 \pm 3.9$ & $89.7 \pm 3.2$ & $41.9 \pm 1.8$ & $79.0 \pm 3.1$ & $51.2 \pm 3.7$ \\
\hline Bz 15 & $59.9 \pm 2.3$ & $36.9 \pm 2.4$ & $50.4 \pm 2.7$ & $58.5 \pm 2.5$ & $55.9 \pm 3.1$ & $43.3 \pm 2.4$ & $68.1 \pm 3.2$ & $61.3 \pm 2.7$ \\
\hline Bz 16 & $47.8 \pm 2.4$ & $36.9 \pm 1.9$ & $51.1 \pm 2.0$ & $52.4 \pm 2.7$ & $71.2 \pm 3.2$ & $40.3 \pm 4.5$ & $78.0 \pm 4.3$ & $52.0 \pm 2.5$ \\
\hline Bz 17 & $66.3 \pm 4.5$ & $45.8 \pm 3.6$ & $61.3 \pm 4.5$ & $64.5 \pm 4.9$ & $73.6 \pm 4.4$ & $41.3 \pm 2.0$ & $76.0 \pm 4.1$ & $65.1 \pm 1.9$ \\
\hline Bz 18 & $78.9 \pm 3.9$ & $59.5 \pm 1.9$ & $67.9 \pm 2.9$ & $92.3 \pm 7.4$ & $66.1 \pm 2.3$ & $43.8 \pm 2.4$ & $62.3 \pm 3.5$ & $60.9 \pm 1.7$ \\
\hline R.Klein & $75.9 \pm 5.6$ & $64.7 \pm 5.2$ & $69.4 \pm 6.4$ & $92.7 \pm 6.3$ & $72.8 \pm 5.5$ & $79.2 \pm 1.2$ & $71.2 \pm 5.4$ & $81.9 \pm 4.0$ \\
\hline E.norli & $76.8 \pm 3.3$ & $70.4 \pm 4.8$ & $87.9 \pm 3.6$ & $106.2 \pm 7.7$ & $78.7 \pm 7.7$ & $72.2 \pm 4.4$ & $84.4 \pm 5.7$ & $98.3 \pm 6.1$ \\
\hline Bolero & $83.3 \pm 6.2$ & $71.8 \pm 5.7$ & $79.9 \pm 5.2$ & $91.3 \pm 5.5$ & $82.1 \pm 6.8$ & $61.5 \pm 3.6$ & $101.7 \pm 7.3$ & $96.9 \pm 6.7$ \\
\hline Sprinter & $92.5 \pm 6.8$ & $75.2 \pm 4.8$ & $82.4 \pm 4.6$ & $97.1 \pm 4.4$ & $96.2 \pm 6.1$ & $68.9 \pm 2.0$ & $106.0 \pm 10.6$ & $97.6 \pm 2.3$ \\
\hline Lancet & $71.4 \pm 3.0$ & $70.0 \pm 2.9$ & $73.0 \pm 2.2$ & $82.2 \pm 4.4$ & $88.9 \pm 3.7$ & $70.0 \pm 3.2$ & $94.8 \pm 4.1$ & $88.5 \pm 4.1$ \\
\hline
\end{tabular}


To find out the effect of environmental factors on the stoma number of the used lines/cultivars, the study was been conducted in the same ecology for 2 years. Pea plant especially in tall forms carry out the vegetative and generative phases together. In this period because vegetative development continues, whether the variations in stoma numbers are caused by the genotype or the development stage won't be able to be understood, therefore in interpreting the changes in genotypes caused by years, the stomata numbers in the leaflet in the pod setting period were considered and given in Fig. 3 and 4.

Stomata number in the abaxial surface of leaflet in cultivars had no apparent interaction with the year (Fig. 3 ) however an interaction was seen in adaxial surface of leaflet (Fig. 4). This interaction is seen in both surfaces in lines. It doesn't seem possible to tell whether data and stomata numbers that come out of the study conducted with 23 lines/cultivars can be used in cultivar differentiation. It will be more correct to determine inheritance values and come to conclusion by increasing environment variation and number of cultivars.

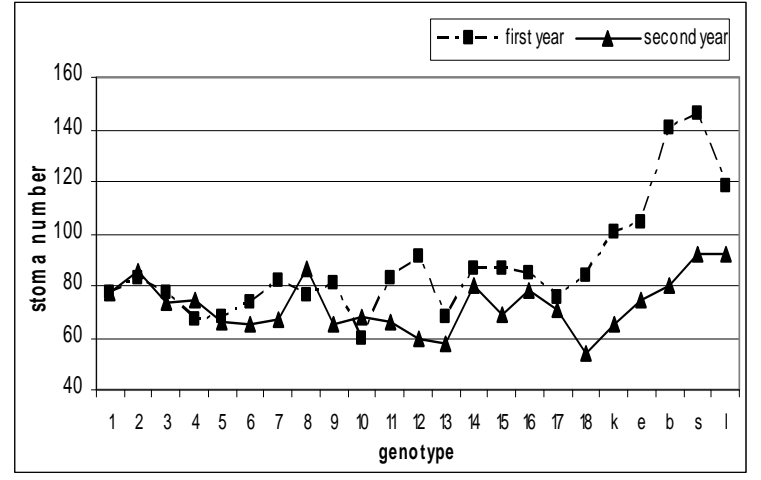

Fig. 3: Change in the stomata number on leaflet abaxial surface of pea genotypes in pod setting period with respect to years

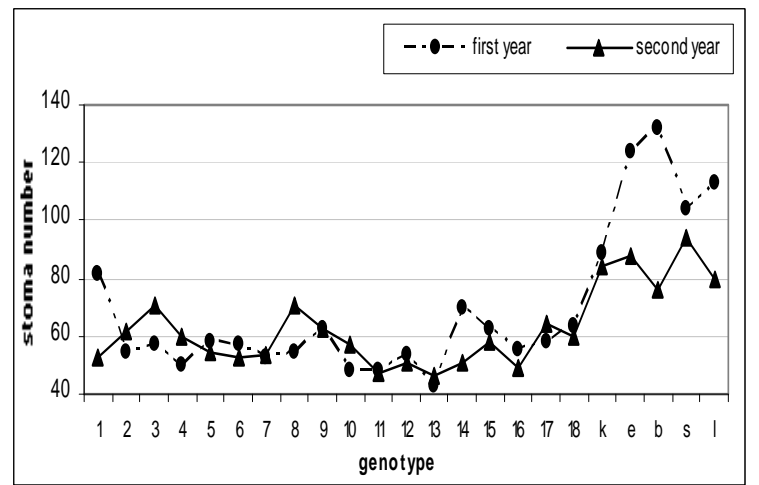

Fig. 4: Change in the stomata number on leaflet adaxial surface of pea genotypes in pod setting period with respect to years
Stomata size and density show variation according to plants species, cultivar, clones and cultivation conditions ${ }^{[10]}$. In the study we conduct in Samsun which has warm climate conditions, the effect of years on the stomata densities can be seen in Table 2. In pod setting period, a difference at the statistical level $(\mathrm{P}<0.01)$ has been observed between all characteristics except for year values of stomata numbers on adaxial surface of stipula and leaflet (Table 2).

In the first year, stomata numbers in all leaf sections have been higher than the second year in both plant development stages (Table 2). In the first year, flowering of plants have occurred between April 1st and 20th and in the second year, it occurred between April 13th and May 5th in varying genotypes. When Fig. 1, which shows the climate values of region, is analyzed, in overall of the whole cultivation period, the rain values of first year were higher than the second year and temperature has generally been close between both years. In the months of April and May when stomatal densities were determined and pod setting has occurred, the differences between temperatures have been very small while the difference between the rainfalls has been higher. In months before this date, more rainfall, which promotes plant development, in the first year and slightly less temperature in the same period may have lengthened the vegetative development of plant and in relation to that increased the stomata number. It was reported that the water amount in plant structure causes change in stomatal density and another researcher ${ }^{[3]}$ highlighted that light level also has effect. In the spring, Samsun goes through a temperate and rainy period and has a quite variant lighting nature. However no light intensity determination has been made in this study. The fact that soil characteristics have been similar in both years of the trial shows that meteorological factors such as rain and light intensity have more effect on stomata number in the unit area.

Stomatal densities in leaf sections in various development stages of pea and their statistical comparisons with each other are given in Table 3. Between all comparisons except for stipula abaxial surface (65.22) in flowering period and stipula abaxial surface (75.47) and leaflet abaxial surface (77.04) in pod setting period, statistical differences have been established (Table 2) The fact that adaxial surface of leaf sections is more open to environmental factors may have caused the change there to be more. In pea which has compound leaves, stipulas have the characteristic to be able to develop as much as or more than leaflets and changes in stomatas indicate that these organelles 
Online J. Biol. Sci.,6 (2):56-61, 2006

function like leaflets.

Table 2: Comparison of leaf sections that change in flowering and pod setting stages by stomata numbers

\begin{tabular}{|c|c|c|c|c|c|c|c|}
\hline Comparison & Mean & Variance & $t$ value & Comparison & Mean & Variance & t value \\
\hline $\begin{array}{l}\text { Abaxial stipula in } \\
\text { flowering (1) }\end{array}$ & 65.58 & 653.7 & \multirow{2}{*}{$11.79 * *$} & 6 & 46.44 & & \multirow[b]{2}{*}{$13.85^{* *}$} \\
\hline $\begin{array}{l}\text { Adaxial stipula in } \\
\text { flowering (2) }\end{array}$ & 50.98 & 492.7 & & $\begin{array}{l}\text { Adax. Leaflet in pod } \\
\text { setting (8) }\end{array}$ & 62.55 & 632.68 & \\
\hline 1 & 65.58 & & \multirow[b]{2}{*}{0.28} & 7 & 77.04 & & \multirow[b]{2}{*}{$11.14 * *$} \\
\hline $\begin{array}{l}\text { Abaxial. leaflet in } \\
\text { flowering (3) }\end{array}$ & 65.22 & 597.5 & & 8 & 62.55 & & \\
\hline 2 & 50.98 & & \multirow[b]{2}{*}{$12.95^{* *}$} & 1 & 65.58 & & \multirow[b]{2}{*}{$7.76^{* *}$} \\
\hline $\begin{array}{l}\text { Adaxial leaflet in } \\
\text { floweing (4) }\end{array}$ & 68.13 & 818.47 & & 5 & 75.47 & & \\
\hline $\begin{array}{l}3 \\
4\end{array}$ & $\begin{array}{l}65.22 \\
68.13\end{array}$ & & $2.11^{*}$ & $\begin{array}{l}2 \\
6\end{array}$ & $\begin{array}{l}50.98 \\
46.44\end{array}$ & & $4.00 * *$ \\
\hline $\begin{array}{l}\text { Abaxial stipula in pod } \\
\text { setting (5) }\end{array}$ & 75.47 & 649.45 & \multirow{2}{*}{$24.79 * *$} & 3 & 65.22 & & \multirow{2}{*}{$8.82 * *$} \\
\hline $\begin{array}{l}\text { Adaxial stipula in pod } \\
\text { setting (6) }\end{array}$ & 46.44 & 533.67 & & 7 & 77.04 & & \\
\hline 5 & 75.47 & & \multirow[b]{2}{*}{1.19} & 4 & 68.13 & & \multirow[b]{2}{*}{$4.16^{* *}$} \\
\hline $\begin{array}{l}\text { Abaxial leaflet in pod } \\
\text { setting ( } 7 \text { ) }\end{array}$ & 77.04 & 825.02 & & 8 & 62.55 & & \\
\hline
\end{tabular}

Table 3: Changes of stomata numbers (count $/ 1 \mathrm{~mm}^{2}$ ) in various leaf sections with respect to years and t comparison values

\begin{tabular}{|c|c|c|c|c|c|}
\hline Surface & Year & Mean & Range & Variance & t value \\
\hline \multicolumn{6}{|c|}{ in flowering period } \\
\hline \multirow{2}{*}{ Abaxial of stipula } & 1 & 84.07 & $46.2-145.8$ & 678.9 & \multirow{2}{*}{$4.73^{* *}$} \\
\hline & 2 & 81.59 & $41.1-79.2$ & 81.6 & \\
\hline \multirow{2}{*}{ Adaxial of stipula } & 1 & 67.74 & $38.9-115.9$ & 550.6 & \multirow{2}{*}{$4.61 * *$} \\
\hline & 2 & 43.14 & $31.9-65.8$ & 104.8 & \\
\hline \multirow{2}{*}{ Abaxial of leafleat } & 1 & 82.50 & $43.1-118.1$ & 479.1 & \multirow{2}{*}{$5.26^{* *}$} \\
\hline & 2 & 56.40 & $43.3-79.4$ & 88.3 & \\
\hline \multirow{2}{*}{ Adaxial of leaflet } & 1 & 93.00 & $40.3-220.1$ & 1760.1 & \multirow{2}{*}{$3.73 * *$} \\
\hline & 2 & 58.70 & 41.4-83.9 & 181.3 & \\
\hline \multirow{3}{*}{ Abaxial of stipula } & & & I setting & & \multirow{3}{*}{$4.67 * *$} \\
\hline & 1 & 85.89 & $70.4-111.1$ & 175.9 & \\
\hline & 2 & 69.07 & $52.8-94.7$ & 122.5 & \\
\hline \multirow{2}{*}{ Adaxial of stipula } & 1 & 54.69 & $32.4-157.6$ & 790.0 & \multirow{2}{*}{1.74} \\
\hline & 2 & 43.80 & $29.4-65.8$ & 99.9 & \\
\hline \multirow{2}{*}{ Abaxial of leaflet } & 1 & 87.43 & $59.7-145.8$ & 475.8 & \multirow{2}{*}{$2.97 * *$} \\
\hline & 2 & 72.40 & $53.9-92.5$ & 109.3 & \\
\hline \multirow{2}{*}{ Adaxial of leaflet } & 1 & 69.18 & $42.8-131.9$ & 653.1 & \multirow{2}{*}{1.06} \\
\hline & 2 & 62.79 & 46.4-93.9 & 183.1 & \\
\hline
\end{tabular}

** $\mathrm{P}<0.01$

Based on the leaf sections, increase of stomata numbers in pod setting period has been determined in the level significant statistical. While in flowering, stomata number in the abaxial surface of the leaflet is 65.22 per $\mathrm{mm} 2$, in pod setting this value increased to 77.04. While in flowering period there were 65.58 stomatas in stipula abaxial surface, in pod setting stage this value was 75.47. In study of pea, were established a more rapid increase in stoma frequency towards the beginning of the flower in bud formation and pod production stages of the mutant they obtained by hybridization ${ }^{[17]}$.

\section{CONCLUSION}

Genetic improvement of cultivars which forms an important pillar of agricultural activity is a difficult and long process. The increase of demand of agricultural products every day requires countries to introduce new products and cultivars and figure out their cultivation methods. Knowing a plant in an ecological, physiological, morphological, cytological and genetic way will make the studies geared towards developing it easier. This study about stomatas has been conducted to make contribution to cultivar development studies on pea which is one of the local genetic sources of our country. According to obtained results, it was clear that meteorological differences effect stomata numbers of plant development and leaf sections and trials have to be continued by considering more cultivars and different environments, cultivation conditions to find out whether it is a characteristic that can be used for cultivar differentiation.

\section{REFERENCES}

1. Akgun, I., M. Tosun and S. Sağsöz, 1998. Bitkisel Gen Kaynaklarının Onemi ve Erzurum'un Bitkisel Gen Kaynakları Yonunden Degerlendirilmesi. Dogu Anadolu Tarım Kongresi 14-18 Eylül, pp: 363-372. 
2. Akcin, A., 1988. Yemeklik Dane Baklagiller (Grain Legume Crops). Selçuk Universitesi Yayınları: 43 Zir. Fak. Yayınları 8, Konya.

3. Brownlee, C., 2001. The long and short of stomatal density signal. Trend in Plant Sci., 6: 441-442.

4. Nabin, S., S.C. Nath and D. Simanta, 2000. Foliar micromorphological characters of few taxa of the genus Aquilaria Lamk growing North_East India. Adv. Plant Sci., 13: 551-558.

5. Sabo, M., M. Bede and V. Vukadinovic, 2001. Correlation between number of stomata and concentration of macro and microelements in some winter wheat (Triticum aestivum L.) genotypes. Acta-Agronomica_Hungarica, 49: 319-327.

6. Kliewer, W.M.J.M., R.H. Kobriger, S.T. Lira, S.T. Lagier and G. Collalto, 1985. Performans of grapivines under wind and water stress conditions. Proc. Intl. Symp. Cool Climate Viticulture and Enology, pp: 198-216.

7. Caglar, S. and H. Tekin, 1999. Farklı Pisticia anaclarına asılanan antepfistıg1 cesitlerinin stoma yogunlukları. (The Stomata Density of Pistachio Cultivars on Different Pistacia Rootstocks) Tur. J. Agri. Forest., 23: (Sup. 5): 1029-1032.

8. Yang-Chuan,Y., D.J. Yu, D.X. Ge, D. Hui and M. Liang, 1998. Studies on stomata of apple leaves. J. Shandong Agril. Univ., 29: 8-14.

9. Bierhuizen, J.F., J.M. Bierhuizen and G.F.P. Martakis, 1984. The effect of light and CO2 on photosynthesis of varius pot plants. Gartenbauswissenschaft, 49: 215-257.

10. Caglar, S., M. Sütyemez and S. Beyazit, 2004. Secilmis bazı ceviz (Juglans regia) tiplerinin stoma yogunlukları.(Stomatal density in some selected walnut (Juglans regia) types). Akdeniz Universitesi Ziraat Fakültesi Dergisi, 17: 169-174.
11. Kara, S. and E. Ozseker, 1999. Farklı anaclar uzerinde asılı yuvarlak cekirdeksiz uzum cesidinin yaprak ozellikleri ve stoma dagılımı uzerinde bir arastirma. Anadolu, 9: 76-85.

12. Yang, T.Z., Y.Q. Yu, D.Y. Le and Z.Y. Mei, 2004. Relationships between ozone injury and stoma parameters and activities of antioxidant enzyme. Acta-Phytoecologica_Sinica, 28: 672-679.

13. Gu, Z.F., W.W. Qing, Z.A. Ping, Z.X. Min, He.H. Le, P.J. Song and C. Run, 2004. Effect of chlorophyll content and stoma density on cucumber resistance to downy mildew. J. Shanghai Univ. Agril. Sci., 22: 381-384.

14. Ozdemir, S., 2002. Yemeklik Tane Baklagil Yetirştiriciliği.(Grain Legume Crops Cultivation) Hasad Yayıncılık. No: 239, s:142, İstanbul.

15. Salisbury, F.B., 1992. Plant Physiology. Fourth Edition. Colorado State University, pp: 682.

16. Elias, P. 1995. Stomata density and size of apple tress growing in irrigated and non-irrigated conditions. Biologia Bratislava, 50: 115-118.

17. Sokolov, V., V. Shumnyi, Ts. Tsonev, V. Stanev, Zh, Danailov, Zh. and K. Dobrinova, 1988. Frequency, size and functional characteristics of the stomata in relation to heterosis in pea. IzvestiaSibirskogo-Otdeleniya-Akademii-Nauk-SSSR,Biologicheskikh-Nauk, (14/2):89-94. 3 of 6 in CAB Abstract. 1989. 